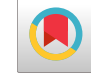

\title{
Association Between Income and Hepatitis B Seroprevalence: A Systematic Review and Meta-analysis
}

\author{
Ye Ding $\mathbb{B}^{1}$, Xueying $\operatorname{Sun}^{1}$, Ying Xu ${ }^{1}$, Ling Yang ${ }^{1}$, Yu Zhang ${ }^{1}$ and Qing Shen ${ }^{1}{ }^{1,}{ }^{*}$ \\ ${ }^{1}$ School of Public Health, Hangzhou Medical College, Hangzhou, China \\ "Corresponding author: School of Public Health, Hangzhou Medical College, 481 Binwen Road, Binjiang District, Hangzhou, 310053, China. Tel: +86-057187692685. Email: \\ sq@hmc.edu.cn \\ Received 2020 May 09; Revised 2020 July 04; Accepted 2020 December 04.
}

\begin{abstract}
Context: Hepatitis B serology is very important for both diagnosis and treatment of the diseases. However, evidence regarding the association between income and hepatitis B seroprevalence are not sufficient to make a definitive conclusion.

Objectives: This meta-analysis aimed to investigate the association between income inequality and hepatitis B seroprevalence. Methods: We searched PubMed and Web of Science databases to identify all relevant epidemiological studies published up to February 10, 2020. A categorical meta-analysis was applied to pool risk effects of income on hepatitis B seroprevalence.

Results: A total of 1525 pieces of literature related to income level and hepatitis B seroprevalence were retrieved, of which 10 articles were finally included. The results revealed a borderline risk (OR: 1.14, 95\%CI: 1.00 - 1.30) for hepatitis B seroprevalence (positive for one or more seromarkers) among low-income groups. A significant income effect was observed for HBsAg seroprevalence with a $28 \%$ higher risk for low income versus high cases (OR:1.28, 95\%CI:1.16 - 1.41). However, no statistically significant associations were found between seroprevalence of Anti-HBs, Anti-HBc, and income.

Conclusions: This study demonstrated that low income may increase the risk of hepatitis B seroprevalence, especially for HBsAg seroprevalence. Programs on hepatitis B prevention should focus on those with low income. Further studies are warranted to establish causality.
\end{abstract}

Keywords: Hepatitis B, Income, Seroprevalence, Meta-analysis

\section{Context}

Hepatitis B virus (HBV) infection is a major public health concern $(1,2)$. According to the World Health Organization, in 2015, the global prevalence of HBV was 3.5\%, corresponding to 257 million carriers of the virus. Most of the patients were concentrated in Africa and Western Pacific regions, accounting for $68 \%$ of all cases (3). Without effective controls, the number of attributable deaths to HBV is expected to be 20 million for the period of 2015 - 2030 (4).

Serum indicators are widely using to accurately screen, diagnose, and treat HBV infected patients (5). According to the guidelines published by the Asian Pacific Association for the Study of the Liver (APASL), the testing serum indicators should include HBsAg, Anti-HBs, and total Anti-HBc. A positive HBsAg test indicates the current hepatitis B infection (6). An anti-HBs positive test ( $\geqq 10 \mathrm{mIU} / \mathrm{mL}$ ) indicates immunity against $\mathrm{HBV}(7)$. However, anti-HBc positive may indicate current or previous HBV infection $(8,9)$. Based on the testing results of hepatitis B seroprevalence, chronic HBV infection can be classified into different phases, which each has its particular treatment. Therefore, hepatitis B serology is very important for the diagnosis and treatment of HBV infection.

According to the literature, income, as a socioeconomic variable, may be causally linked to health $(10,11)$. Besides, it is a risk factor for infectious diseases (i.e., HIV, diarrhea), and also it affects the development of noninfectious diseases (i.e., diabetes, diarrhea, asthma, and cardiovascular diseases) $(12,13)$. Not surprisingly, there are also evidence regarding the association between income inequality and hepatitis B seroprevalence. However, results regarding this issue are controversial. For example, Zhang et al. reported that low income is associated with an increased risk of HBsAg seroprevalence (OR: 1.23, 95\%CI: $1.07-1.42$ ) (14). Meanwhile, there are studies that reported no significant association between income inequality and HBsAg seroprevalence(OR: 0.89, 95\%CI: 0.63-1.27)(15). Such 
mixed results might be attributed to the heterogeneity of studies.

\section{Objectives}

In this study, we tried to address the abovementioned gap in the literature. We aimed to investigate the association between income inequality and hepatitis B seroprevalence, defined as the prevalence of any hepatitis B seromarker. We hope our results be helpful for hepatitis B prevention.

\section{Data Sources}

In this meta-analysis, the preferred reporting items for systematic reviews and meta-analyzes (PRISMA) standards were used as the guideline. We searched PubMed and Web of Science databases for articles published up to February 10, 2020. The search strategies were as follows: in PubMed, ("Hepatitis B"[Mesh]) AND "Socioeconomic Factors"[Mesh]; in Web of Science, (TS = Hepatitis B) AND (TS = ("social status" OR socioeconomic OR socioeconomic OR inequality* OR income OR earning* OR wage*)). Four of the authors (XYS, YX, LY, and YZ) were divided into 2 pairs, and each pair screened all titles and abstracts. If either pair included the article, the full-text paper was obtained for further reviewing. References of all articles as well as published relevant reviews were also independently double-checked by the two pairs. In case of a disagreement, a consensus was reached through discussion.

\section{Study Selection}

We included quantitative studies on the association between income inequality and hepatitis B Sero-prevalence. Inclusion criteria were: (a) Chinese or English language; (b) assessing the income (either in currency or grade); (c) case-control design, and (d) reporting odds ratio (OR) and its corresponding 95\% confidence intervals (CIs), or reporting sufficient data to calculate these indicators. Besides, there were no restrictions regarding the age of respondents in our literature search. Exclusion criteria were nondata-based studies, such as reviews. The previously published articles of the same study were also excluded; that is, only the most updated one was included. We also excluded the articles if the income assessment was based on ownership of car, house, health insurance and etc.

\section{Data Extraction}

For each eligible study, the following information were extracted by 2 of the authors (LY and YZ), including authors, publication year, country, study design, hepatitis B seromarkers, sample size, seropositive numbers, gender, age, income inequality type, and levels, statistical modeling, statistical parameters, OR and its 95\%CIs.

Using the Newcastle-Ottawa Scale (16), quality assessments were independently performed by 2 reviewers (XYS and YX). Articles with 0 - 4 scores were considered to be of the lowest quality, and score $\geq 7$ were considered to be of the highest quality. The discrepancies were resolved by discussion.

\subsection{Exposure and Outcome}

Income was considered as the exposure factor, which was grouped differently across studies. If the income is divided into 3 levels in the original text, then in this study, the two higher levels are combined into the "high income group", and the lowest level is the "low income group".; in original studies with 4 inequality groups, the 2 higher income levels were pooled as the reference group to compare with the 2 lower income levels.

Hepatitis B seroprevalence was considered as the outcome. All hepatitis B seromarkers reported in the literature were included in this meta-analysis. Although some literature reported multiple seromarkers without subdividing them separately, these markers were still included in our study and classified as a "mixed group" in the subgroup analysis.

\subsection{Statistical Analysis}

The multivariate-adjusted ORs were included if they were reported in the original literature; otherwise, the unadjusted ORs were calculated using the original data. The forest plots for the association between income and hepatitis B seroprevalence were generated for high-income level versus low-income level.

Heterogeneity was assessed using Cochrane's Q test (17) and $\mathrm{I}^{2}$ statistic (18). Heterogeneity was present if the P-value of the $\mathrm{Q}$ test was $<0.1$ or $\mathrm{I}^{2}>50 \%$. A fixedeffects model was performed when no statistically significant heterogeneity was observed; otherwise, a randomeffects model was conducted for pooling ORs simultaneously. Meanwhile, subgroup analysis was performed to explore potential sources of heterogeneity, which was stratified by gender, region, marker, and quality score. 
Egger's linear regression (19) and Begg's rank correlation (20) were used to assessing publication bias. The sensitivity analysis was also conducted using the leave-one-out approach to evaluate the influence of each study on the pooled estimate.

Statistical analyses were performed using STATA version 14.0 (STATA Corp, College Station, Texas).

\section{Results}

\subsection{Literature Search and Study's Characteristics}

The PRISMA flowchart of the literature screening is illustrated in Figure 1. The Searches of the 2 databases using the search strategy as well as hand-searching reference lists identified 1,525 potential articles. After screening the titles and abstracts, 1,499 articles were excluded as they were duplicated or irrelevant to our study aims. Full-text reports were obtained for 26 articles. Of these, 16 articles were excluded as 6 studies were against the inclusion of income type, 7 studies didn't have income factor, and 3 studies were not focused on the hepatitis B seromarkers. Thus, 10 studies $(14,15,21-28)$ were included in this meta-analysis.

The methodological "quality" of these 10 studies were assessed based on the Newcastle-Ottawa Scale. The scores range from 5 (the lowest) to 9 (the highest): 2 articles were $5-6$ and 8 articles were $>7$. None of them was $\leq 4$.

The detailed characteristics of the included studies were shown in Table 1 . A total of 10 studies assessed the association between income and HBsAg seroprevalence $(\mathrm{N}=$ $5)$, Anti-HBs ( $\mathrm{N}=3)$, Anti-HBc $(\mathrm{N}=3)$, and mixed markers (reported 2 or more markers, $\mathrm{N}=5$ ). Moreover, 6 of the 10 studies were from Asian counties, with 3 studies reported from China. A number of studies were conducted in specific populations: 1 for rural women of childbearing age (14), 1 for pregnant women (25), 1 for school-age children (23). The most common measure of income was household income $(\mathrm{N}=7)$, while 3 was personal income. The majority $(\mathrm{N}=8)$ studies measured income in currency, and 2 studies measured income in grade.

\subsection{Income and Hepatitis B Seroprevalence}

Pooled ORs (95\% CIs) were calculated for hepatitis B seroprevalence among people in low income group compared with those in the high income group (Figure 2). The results revealed a borderline risk (OR:1.14, 95\%CI:1.00-1.30) for hepatitis B seroprevalence (positive for 1 or more seromarkers) among low-income groups (Figure 2A). A significant income effect was observed for HBsAg seroprevalence
(Figure 2B), with a $28 \%$ higher risk for low income versus high one (OR: 1.28, 95\%CI: 1.16 - 1.41). However, no statistically significant associations were found between seroprevalence of Anti-HBs, Anti-HBc, and income (Figure 2C and D).

\subsection{Subgroup Analysis}

With reference to Figures 2A, degrees of heterogeneity were relatively high in this meta-analysis $\left(I^{2}=68.5 \%, P<\right.$ 0.001). To identify the source of heterogeneity, subgroup analysis was conducted based on gender, region, marker, and quality scores (Table 2). However, high degrees of heterogeneity were still found within most subgroup analyses.

Moreover, a marginally significant association was found between low income and hepatitis B seroprevalence among females (OR: 1.23, 95\%CI: 1.11 - 1.38) and those from non-Asian regions (OR: 1.21, 95\%CI: $1.02-1.44$ ), as well as in studies $<7$ scores (OR:1.23, 95\%CI: $1.07-1.41$ ).

\subsection{Sensitivity and Publication Bias Analysis}

In the sensitivity analysis for HBsAg (Figure 3B) and Anti-HBc (Figure 3D), the omission of any 1 study did not result in significant change in outcomes. However, based on the sensitivity analysis of all seromarkers and anti-HBs, no evident change was observed at pooled results if a certain study were omitted. Concerning the association between income and the seroprevalence of all markers, the omission of any 1 study altered the pooled ORs quantitatively. (Figure 3A). Also, if a certain study was removed, the low income was a risk factor for Anti-HBs seroprevalence (Figure $3 C$ ). The results of the Egger's and Begg's tests (Figure 4 , both $\mathrm{P}>0.05$ ) revealed no publication bias.

\section{Conclusions}

In the current meta-analysis, we intended to comprehensively review the evidence on the association between income and hepatitis B seroprevalence. Based on the findings, there was a significant association between pooled effect sizes of income and HBsAg seroprevalence. The results also revealed a borderline significant association between income and hepatitis B seroprevalence (positive for 1 or more seromarkers). However, the association between income and Anti-HBs seroprevalence was not statistically significant. The same was true about the association between income and Anti-HBc seroprevalence. 
Table 1. Characteristics of Case-Contorl Studies Included in the Meta-Analysis of Income and Hepatitis B Seroprevalence

\begin{tabular}{|c|c|c|c|c|c|c|c|c|c|c|c|}
\hline Id & First Author & Year & Country & $\begin{array}{l}\text { Hepatitis B } \\
\text { Seromarkers }\end{array}$ & $\begin{array}{l}\text { No of } \\
\text { Samples }\end{array}$ & $\begin{array}{l}\text { No of } \\
\text { Positive }\end{array}$ & Gender & Age & Income Type & Income Level & $\begin{array}{l}\text { Covariates in Multivariate } \\
\text { Analysis }\end{array}$ \\
\hline 1 & Zhang (14) & 2013 & China & $\operatorname{HBsAg}(+)$ & 12393 & 1179 & $\mathrm{~F}$ & $15-49$ & $\begin{array}{c}\text { Family } \\
\text { monthly } \\
\text { income (RMB) }\end{array}$ & $\begin{array}{l}<2000 ; \geq \\
2000\end{array}$ & Univariate analysis. \\
\hline 2 & $\operatorname{Liu}(21)$ & 2019 & China & $\operatorname{HBsAg}(+)$ & 10256 & 783 & $\mathrm{~F} \& \mathrm{M}$ & $\geq 18$ & $\begin{array}{c}\text { Monthly } \\
\text { household } \\
\text { income (HKD) }\end{array}$ & $\begin{array}{l}<10000 \\
10001-20000 \\
20001-30000 \\
\quad>30000\end{array}$ & $\begin{array}{l}\text { Sex; Age; Place of birth; Monthly } \\
\text { household income; Hepatititi B } \\
\text { vaccination; HBV carriage in } \\
\text { mother; HBV carriage in other } \\
\text { family members; Previous blood } \\
\text { transfusion; Illicit intravenous } \\
\text { drug use; Skin tattoo; } \\
\text { Hemodialysis; Chronic illness; } \\
\text { Residential district; Household } \\
\text { income. }\end{array}$ \\
\hline 3 & $\begin{array}{c}\text { Fathimoghaddam } \\
\text { (26) }\end{array}$ & 2011 & Iran & $\operatorname{HBsAg}(+)$ & 1652 & 23 & $\mathrm{~F} \& \mathrm{M}$ & $1-90$ & $\begin{array}{c}\text { Household } \\
\text { monthly } \\
\text { income(Rials) }\end{array}$ & $\begin{array}{l}<\text { 3million; } \\
\text { 3-5million;> } \\
\text { 5million }\end{array}$ & $\begin{array}{l}\text { Age; Marital Status; Ethnic } \\
\text { background; Traditional cupping. }\end{array}$ \\
\hline 4 & $\begin{array}{l}\text { Mutocheluh } \\
\quad(27)\end{array}$ & 2014 & Ghana & $\operatorname{HBsAg}(+)$ & 164 & 24 & $\mathrm{~F} \& \mathrm{M}$ & $17-57$ & $\begin{array}{l}\text { Average } \\
\text { income level } \\
\text { of subjects }\end{array}$ & $50 ; 80 ; 100$ & $\begin{array}{l}\text { Level of education (Stepwise } \\
\text { regression method). }\end{array}$ \\
\hline 5 & Khouri (22) & 2010 & Brazil & Anti-HBc (+) & 243 & 99 & $\mathrm{~F} \& \mathrm{M}$ & $1-87$ & $\begin{array}{l}\text { Annual family } \\
\text { Income (BRL) }\end{array}$ & $\begin{array}{l}\leq 2000 ;> \\
2000\end{array}$ & $\begin{array}{l}\text { Anti-HCV; Area; Age; } \\
\text { Hospitalization; Sexual activity; } \\
\text { Partners (Last year). }\end{array}$ \\
\hline 6 & Khouri (28) & 2005 & Brazil & Anti-HBc (+) & 267 & 165 & $\mathrm{~F} \& \mathrm{M}$ & $5-81$ & $\begin{array}{c}\text { Annual } \\
\text { income (US\$) }\end{array}$ & $\begin{array}{l}\leq 1015.22 ;> \\
1015.22\end{array}$ & $\begin{array}{l}\text { Gender; Age; State of birth; Time of } \\
\text { residency in Monte Negro; } \\
\text { Interviewee's occupation. }\end{array}$ \\
\hline 7 & $\begin{array}{l}\text { Luksamijarulkul } \\
\qquad(23)\end{array}$ & 1995 & Thailand & $\begin{array}{l}\operatorname{HBsAg}(+) \text { or } \\
\text { Anti-HBs (+) or } \\
\text { Anti-HBc (+) or } \\
2 \text { makers (+) of } \\
\text { them }\end{array}$ & 165 & 41 & $\mathrm{~F} \& \mathrm{M}$ & 6-14 & $\begin{array}{l}\text { Family income } \\
\text { per month } \\
\text { (baht) }\end{array}$ & $\begin{array}{l}<4500 ; \geq \\
4500\end{array}$ & $\begin{array}{l}\text { Ear piercing in female (Stepwise } \\
\text { regression method). }\end{array}$ \\
\hline 8 & Bertolini (25) & 2006 & Brazil & $\begin{array}{l}\operatorname{HBsAg}(+) \text { or } \\
\text { Anti-HBs (+) or } \\
\text { Anti-HBc (+) or } \\
2 \text { makers }(+) \text { of } \\
\text { them }\end{array}$ & 3188 & 591 & $\mathrm{~F}$ (pregnant) & $12-44$ & $\begin{array}{l}\text { Family income } \\
\text { (times } \\
\text { minimum } \\
\text { wage) }\end{array}$ & $<2 ; 2-5 ;>5$ & $\begin{array}{l}\text { Age; Color; Family origin; Internal } \\
\text { migration from South region } \\
\text { states. }\end{array}$ \\
\hline \multirow{3}{*}{9} & \multirow{3}{*}{ Zhang (15) } & \multirow{3}{*}{2011} & \multirow{3}{*}{ China } & Anti-HBc (+) & \multirow{3}{*}{3833} & 1567 & \multirow{3}{*}{$\mathrm{F} \& \mathrm{M}$} & \multirow{3}{*}{$18-79$} & \multirow{3}{*}{$\begin{array}{l}\text { Yearly income } \\
\quad \text { (RMB) }\end{array}$} & \multirow{3}{*}{$>800 ; \leq 800$} & \multirow{3}{*}{$\begin{array}{l}\text { Age; Gender; Drinking; Smoking; } \\
\text { Sleep quality; Family size; } \\
\text { Occupation; Income; Personal } \\
\text { history of vaccination; Family } \\
\text { history of HBV. }\end{array}$} \\
\hline & & & & $\begin{array}{l}\text { Anti-HBs (+) } \\
\text { and Anti-HBC } \\
\qquad(-)\end{array}$ & & 471 & & & & & \\
\hline & & & & $\begin{array}{l}\text { Anti-HBs (+) } \\
\text { and Anti-HBc } \\
\qquad(+)\end{array}$ & & 865 & & & & & \\
\hline \multirow{4}{*}{10} & \multirow{4}{*}{ Kahraman (24) } & \multirow{4}{*}{2018} & \multirow{4}{*}{ Turkey } & & 350 & 263 & \multirow{4}{*}{$\mathrm{F} \& \mathrm{M}$} & $2 \cdot 21$ & \multirow{4}{*}{$\begin{array}{l}\text { Annual per } \\
\text { capita } \\
\text { equivalent } \\
\text { income(TL) }\end{array}$} & \multirow{4}{*}{$\leq_{3265}^{3265 ;>}$} & \multirow{4}{*}{$\begin{array}{l}\text { Age; Gender; Area of living; Area of } \\
\text { living during childhood; } \\
\text { Professional status; Perceived } \\
\text { income level; Annual per capita } \\
\text { equivalent income; Household } \\
\text { density. }\end{array}$} \\
\hline & & & & & 880 & 81 & & $22-89$ & & & \\
\hline & & & & \multirow{2}{*}{$\begin{array}{l}\mathrm{HBSAg}(+) \text { or } \\
\text { Anti-HBc(+) or } \\
\text { both }\end{array}$} & 350 & 10 & & $2-21$ & & & \\
\hline & & & & & 880 & 251 & & 22.89 & & & \\
\hline
\end{tabular}


Literature searches $(\mathrm{N}=1525)$

Databases $(\mathrm{N}=1408)$

A manual search for references $(\mathrm{N}=117)$

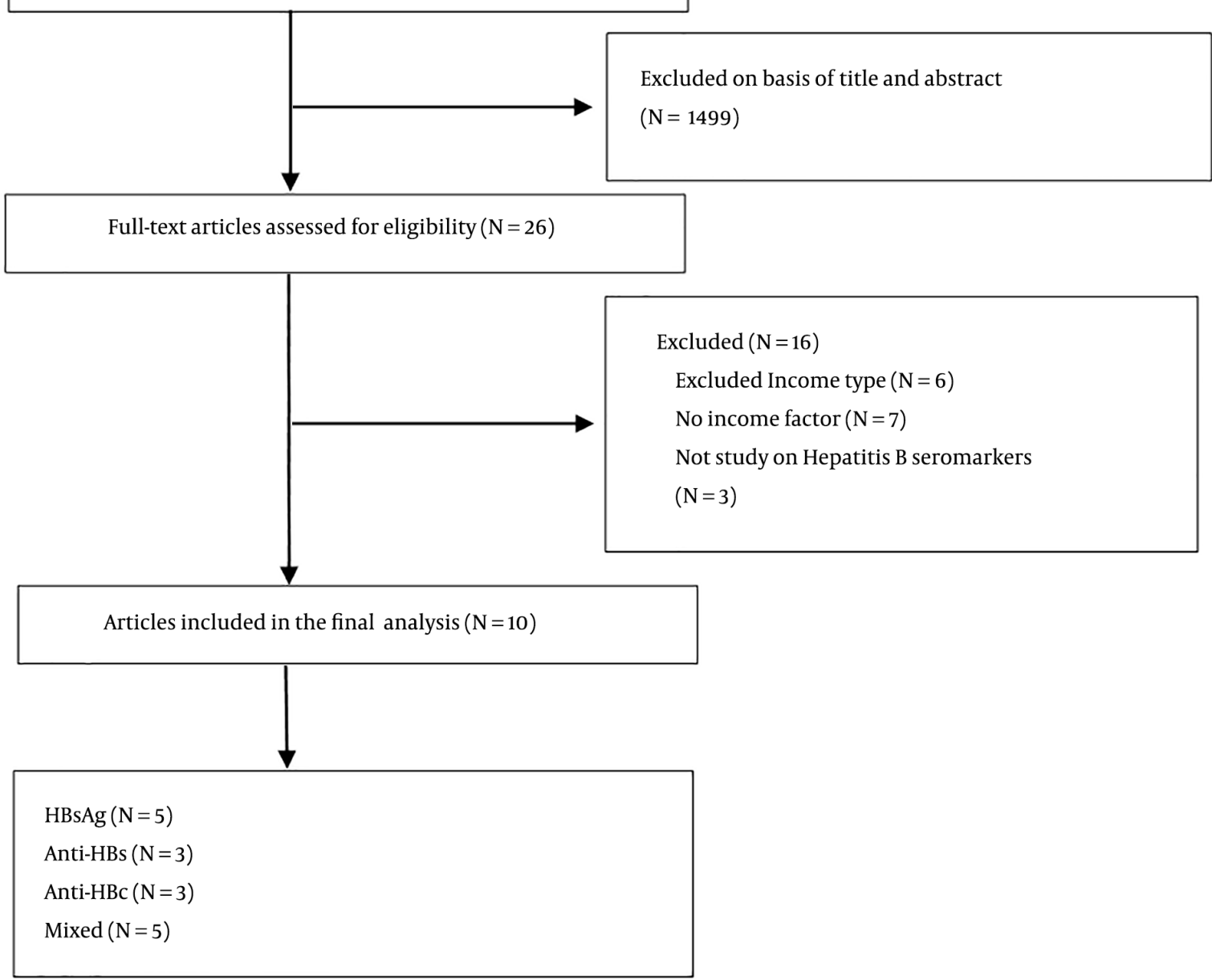

Figure 1. Flowchart of study selection.

HBsAg is an antigen on the surface of HBV that indicates current hepatitis B infection. Currently, vaccination is the most effective mean to prevent HBV infection, which can decrease the HBsAg seroprevalence (29). According to the findings of the present study, income inequality is associated with an increased risk of HBsAg seroprevalence. This might because income is one of the determinants of willingness to pay for the hepatitis B vaccine, and the lower the income, the lower would be the willingness to pay (30). Moreover, compared to those from higher income groups, those with lower income usually have lower levels of awareness about hepatitis B (31) and often have worse living habits (i.e., sharing toothbrushes, razor or nail clippers) (32), which both increase the risk of HBV infection.

As mentioned above, income contributes to the willingness to pay for the HBV vaccine (33-35). Based on this guess, income inequality should be associated with AntiHBs. However, no statistically significant association was found between income and Anti-HBs seroprevalence. However, this can be due to the inadequacy of literature and the low number of studies that were investigated in the present study. 
A

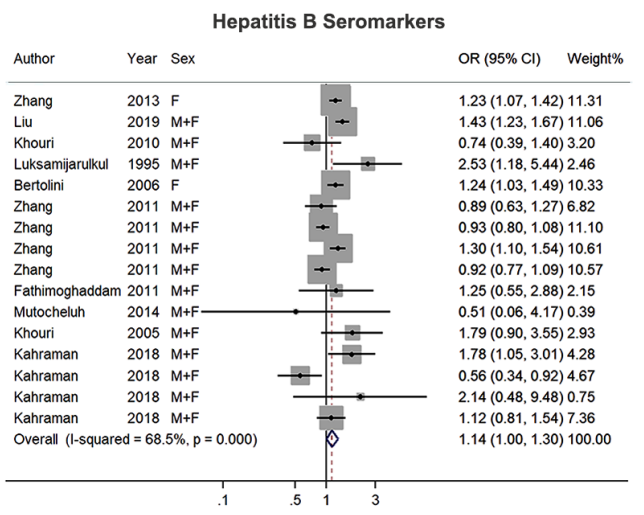

C

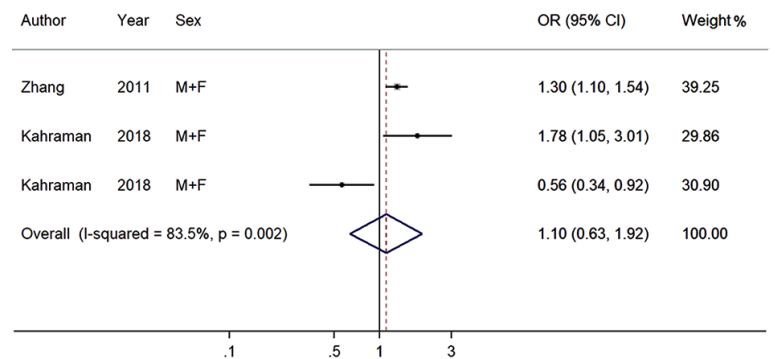

B

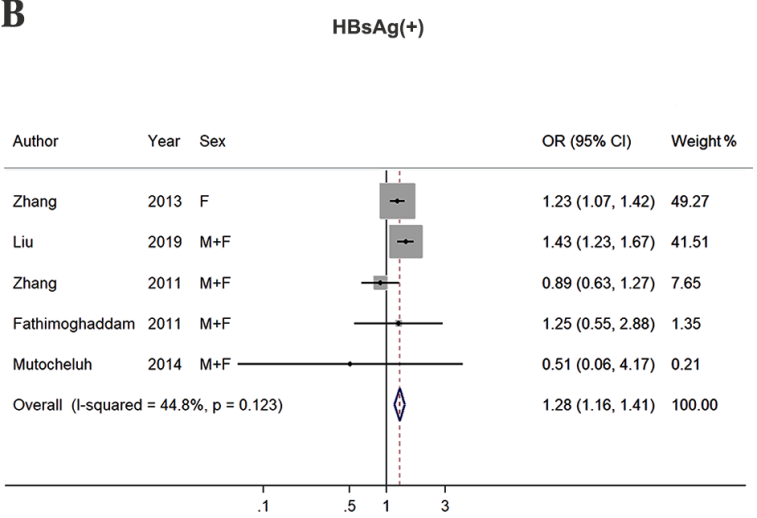

D

Anti-HBc (+)

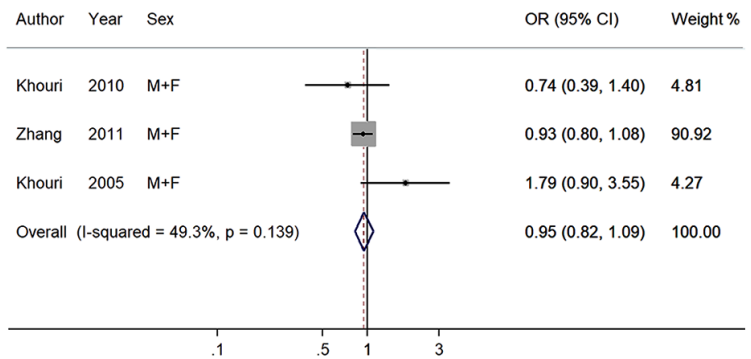

Figure 2. Forest plots for pooled odd ratios (ORs) and the corresponding 95\% confidence intervals (CIs) of hepatitis B seroprevalence for low-income group

To the best of our knowledge, this is the first metaanalysis assessing income effects on hepatitis B seroprevalence. However, there are limitations to our study, which should be noted. First, pooled estimates were affected by high heterogeneity. Although we performed a subgroup analysis separated by gender, region, marker, and quality score, we couldn't identify the source of heterogeneity. Second, we couldn't calculate the difference between subgroups (i.e., the different distribution of seroprevalence of different markers among various income groups), because in one study the sample size of seropositive people was not clear (24). Third, all included studies were case-control studies, which are prone to recall bias. Fourth, the results of sensitivity analysis for hepatitis B seroprevalence (positive for 1 or more seromarkers) and Anti-HBs were both inconsistent. In other words, the associations between income and hepatitis B seroprevalence (positive for 1 or more seromarkers) and anti-HBs were not yet clear.

By taking these limitations into account, future research should pay more attention to the association between anti-HBS and income, so as to provide more mate- rial for meta-analysis. Additionally, future studies should aim to unpack the mechanism underlying the association between income and hepatitis B seroprevalence, in particular, to identify the potential factors that influence this association.

In conclusion, this study demonstrated a positive association between low income and risk of HBsAg seroprevalence. Hence, public health programs, particularly those related to hepatitis B prevention, should pay special attention to income inequality, in addition to emphasizing lowincome populations.

\section{Footnotes}

Authors' Contribution: Ye Ding performed the data analysis and wrote the manuscript. Xueying Sun, Ying Xu, Ling Yang, and Yu Zhang screened the literature, extracted the data, and assessed the quality of the paper. Qing Shen conceived the idea and design of this study.

Conflict of Interests: We declare that we have no conflict of interest. 

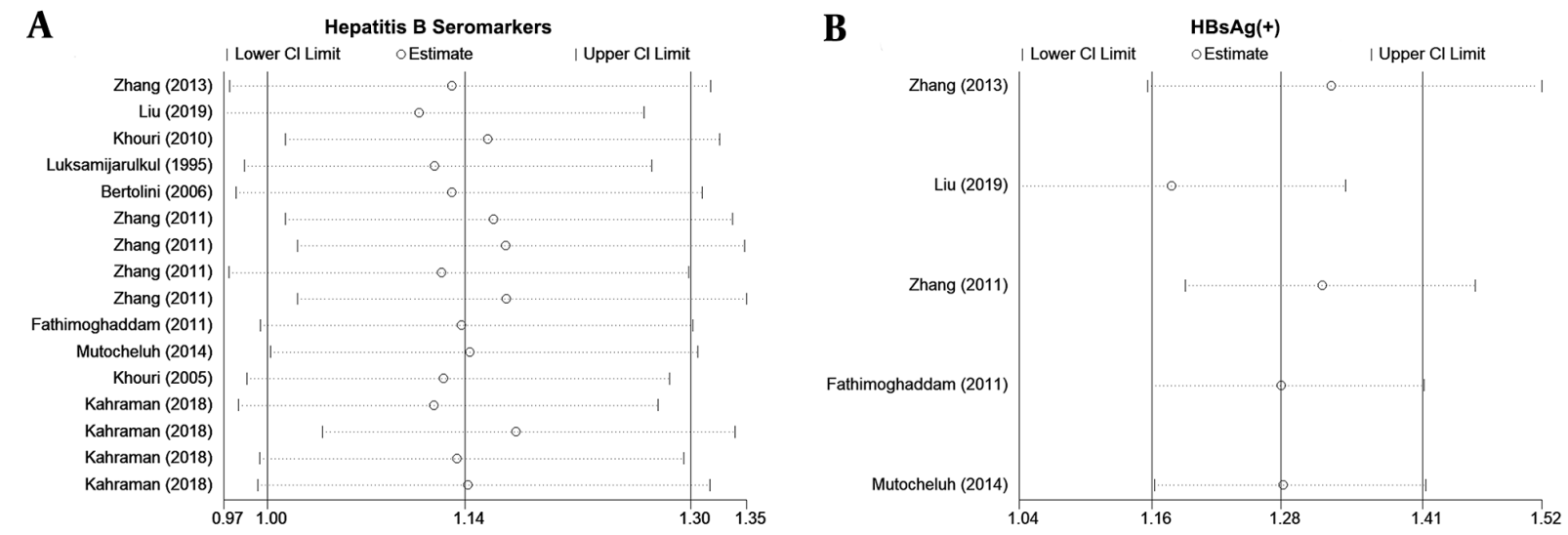

C

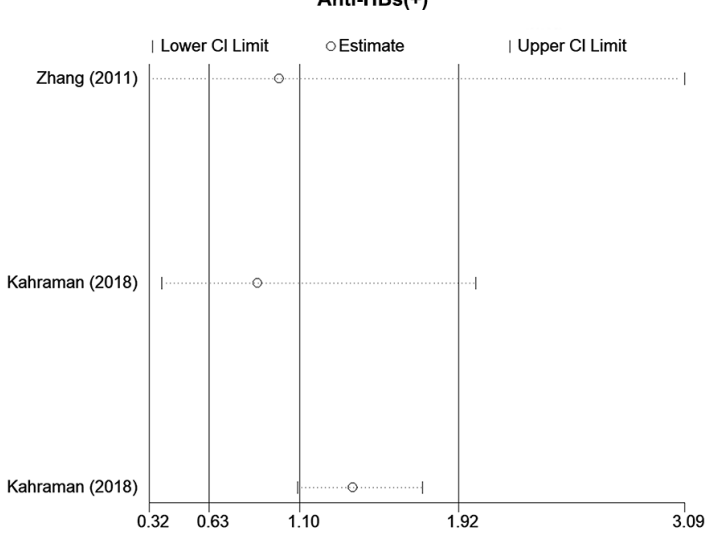

D

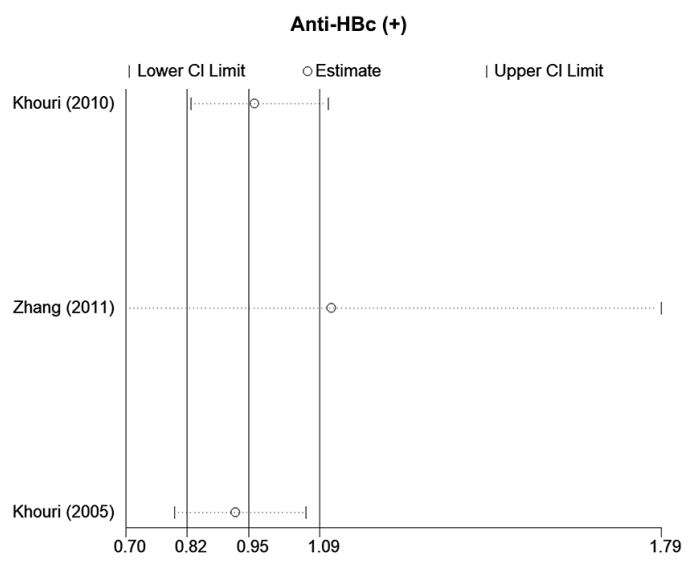

Figure 3. Results of sensitivity analysis.
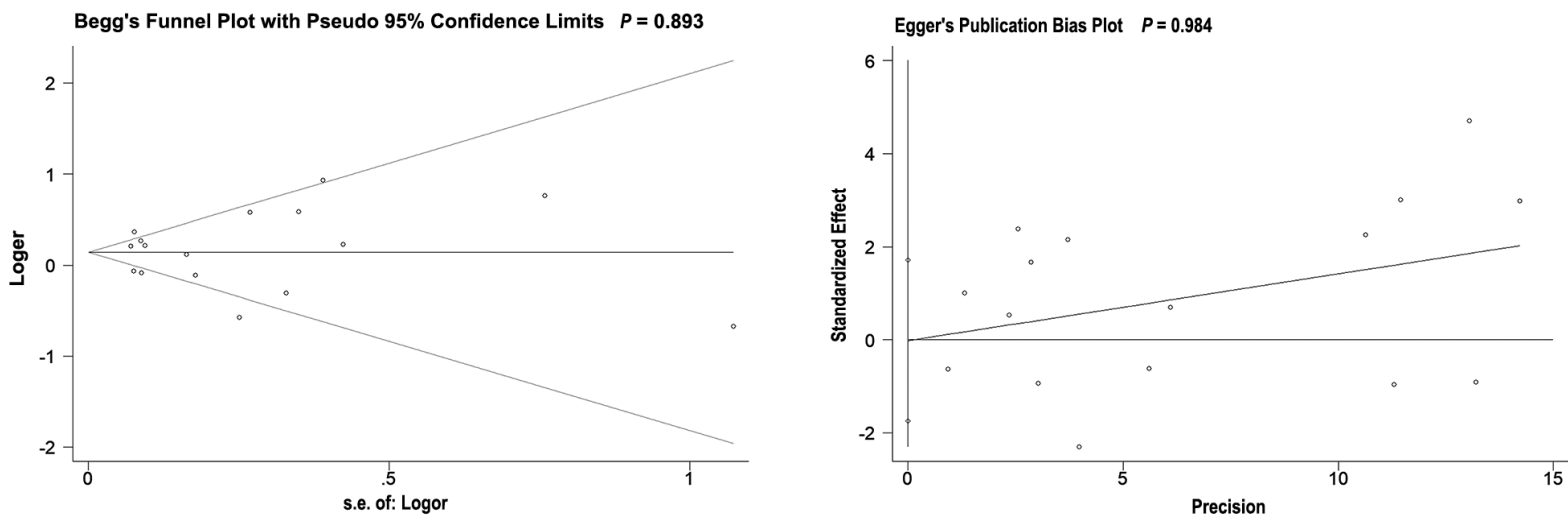

Figure 4. Funnel plot of publication bias testing results (10 included papers including 16 studies of different hepatitis B seromarkers: $\mathrm{HBsAg}(5), \mathrm{Anti}-\mathrm{HBs}(3), \mathrm{Anti}-\mathrm{HBc}(3)$ and Mixed (5)). 


\begin{tabular}{|c|c|c|c|c|}
\hline & \multicolumn{4}{|c|}{ All Hepatitis B Seromarkers } \\
\hline & $\mathbf{N}^{\mathrm{a}}$ & OR $(95 \% \mathrm{CI})$ & $\mathbf{I}^{2}(\%)$ & P Value of Heterogeneity \\
\hline Overall & 10 & $1.14(1.00-1.30)$ & 68.5 & $<0.001$ \\
\hline \multicolumn{5}{|l|}{ Gender } \\
\hline Female & 2 & $1.23(1.11-1.38)$ & 0.0 & 0.985 \\
\hline Male + Female & 8 & $1.12(0.95-1.33)$ & 71.4 & $<0.001$ \\
\hline \multicolumn{5}{|l|}{ Region } \\
\hline Asia & 6 & $1.14(0.98-1.33)$ & 74.4 & $<0.001$ \\
\hline Others & 4 & $1.21(1.02-1.44)$ & 29.3 & 0.236 \\
\hline \multicolumn{5}{|l|}{ Marker $^{\text {b }}$} \\
\hline HBsAg & 5 & $1.28(1.16-1.41)$ & 44.8 & 0.123 \\
\hline Anti-HBs & 3 & $1.10(0.63-1.92)$ & 83.5 & 0.002 \\
\hline Anti-HBc & 3 & $0.95(0.82-1.09)$ & 49.3 & 0.139 \\
\hline Mixed & 5 & $1.18(0.92-1.50)$ & 63.7 & 0.026 \\
\hline \multicolumn{5}{|l|}{ Quality score } \\
\hline$\geq 7$ scores & 8 & $1.14(0.98-1.33)$ & 71.7 & $<0.001$ \\
\hline$<7$ scores & 2 & $1.23(1.07-1.41)$ & 0.0 & 0.411 \\
\hline
\end{tabular}

${ }^{\mathrm{a}}$ The number of studies included.

${ }^{\mathrm{b}}$ Studies which reported or could calculate the seromarker-specific estimates were selected.

Ethical Approval: No ethical considerations were needed to be stated in this paper.

Funding/Support: This study was supported by General Project of Department of Education of Zhejiang Province (grant number: Y201840321). The funders had no role in the study design, data collection, and analysis, decision to publish, or preparation of the manuscript.

\section{References}

1. Lavanchy D. Worldwide epidemiology of HBV infection, disease burden, and vaccine prevention. J Clin Virol. 2005;34 Suppl 1:S1-3. doi: 10.1016/s1386-6532(05)00384-7. [PubMed: 16461208].

2. Nguyen MH, Wong G, Gane E, Kao JH, Dusheiko G. Hepatitis B virus: Advances in prevention, diagnosis, and therapy. Clin Microbiol Rev. 2020;33(2). doi: 10.1128/CMR.00046-19. [PubMed: 32102898]. [PubMed Central: PMC7048015].

3. WHO. Global hepatitis report 2017. World Health Organization; 2017. Available from: https://www.who.int/hepatitis/publications/globalhepatitis-report2017/en/.

4. WHO. Global health sector strategy on viral hepatitis 2016-2021. World Health Organization; 2016. Available from: https://www.who.int/ hepatitis/strategy2016-2021/ghss-hep/en/.

5. European Association for the Study of the Liver. EASL 2017 clinical practice guidelines on the management of hepatitis $B$ virus infection. J Hepatol. 2017;67(2):370-98. doi: 10.1016/j.jhep.2017.03.021. [PubMed: 28427875].

6. Kumar A, Pant S, Narang S. Significance of alanine aminotransferase testing in diagnosis of acute and chronic HBV infection. Asian Pac J Cancer Prev. 2009;10(6):1171-2. [PubMed: 20192606].

7. Sanchez-Fueyo A, Rimola A, Grande L, Costa J, Mas A, Navasa M, et al. Hepatitis B immunoglobulin discontinuation followed by hepatitis B virus vaccination: A new strategy in the prophylaxis of hepatitis B virus recurrence after liver transplantation. Hepatology. 2000;31(2):496-501. doi: 10.1002/hep.510310233. [PubMed: 10655276].

8. Huang X, Hollinger FB. Occult hepatitis B virus infection and hepatocellular carcinoma: a systematic review. J Viral Hepat. 2014;21(3):15362. doi: 10.1111/jvh.12222. [PubMed: 24438677].

9. Wong VW, Chan HL. Severe acute exacerbation of chronic hepatitis B: a unique presentation of a common disease. J Gastroenterol Hepatol.2009;24(7):1179-86. doi: 10.1111/j.1440-1746.2009.05924.x. [PubMed: 19682192].

10. Marmot M. The influence of income on health: views of an epidemiologist. Health Aff (Millwood). 2002;21(2):31-46. doi: 10.1377/hlthaff.21.2.31. [PubMed: 11900185].

11. Lynch J, Smith GD, Harper S, Hillemeier M, Ross N, Kaplan GA, et al. Is income inequality a determinant of population health? Part 1. A systematic review. Milbank Q. 2004;82(1):5-99. doi: 10.1111/j.0887-378x.2004.00302.x. [PubMed: 15016244]. [PubMed Central: PMC2690209].

12. Lopez R. Income inequality and self-rated health in US metropolitan areas: a multi-level analysis. Soc Sci Med.2004;59(12):2409-19. doi: 10.1016/j.socscimed.2004.03.033. [PubMed: 15474197].

13. Shangren Q, Zirui H, Ye D. Income-related inequalities in chronic disease situation among the Chinese population aged above 45 years. Inquiry. 2019;56:46958019860383. doi: 10.1177/0046958019860383. [PubMed: 31431097]. [PubMed Central: PMC6704424].

14. Zhang Y, Fang W, Fan L, Gao X, Guo Y, Huang W, et al. Hepatitis B surface antigen prevalence among 12,393 rural women of childbearing age in Hainan Province, China: a cross-sectional study. Virol J. 
2013;10:25. doi: 10.1186/1743-422X-10-25. [PubMed: 23332007]. [PubMed Central: PMC3626832].

15. Zhang H, Li Q, Sun J, Wang C, Gu Q, Feng X, et al. Seroprevalence and risk factors for hepatitis $B$ infection in an adult population in Northeast China. Int J Med Sci. 2011;8(4):321-31. doi: 10.7150/ijms.8.321. [PubMed: 21611114]. [PubMed Central: PMC3100740].

16. Peterson J, Welch V, Losos M, Tugwell PJOOHRI. The Newcastle-Ottawa scale (NOS) for assessing the quality of nonrandomised studies in meta-analyses. Ottawa. Ottawa Hospital Research Institute; 2011.

17. Higgins JP, Thompson SG. Quantifying heterogeneity in a metaanalysis. Stat Med.2002;21(11):1539-58. doi: 10.1002/sim.1186. [PubMed: 12111919].

18. Higgins JP, Thompson SG, Deeks JJ, Altman DG. Measuring inconsistency in meta-analyses. BMJ. 2003;327(7414):557-60. doi 10.1136/bmj.327.7414.557. [PubMed: 12958120]. [PubMed Central: PMC192859].

19. Hayashino Y, Noguchi Y, Fukui T. Systematic evaluation and comparison of statistical tests for publication bias.J Epidemiol.2005;15(6):23543. doi: 10.2188/jea.15.235. [PubMed: 16276033].

20. Begg CB, Mazumdar M. Operating characteristics of a rank correlation test for publication bias. Biometrics. 1994;50(4):1088-101. [PubMed: 7786990].

21. Liu KSH, Seto WK, Lau EHY, Wong DK, Lam YF, Cheung KS, et al A territorywide prevalence study on blood-borne and enteric viral hepatitis in Hong Kong. J Infect Dis. 2019;219(12):1924-33. doi 10.1093/infdis/jiz038. [PubMed: 30668746].

22. El Khouri M, Cordeiro Q, Luz DA, Duarte LS, Gama ME, Corbett CE. Endemic hepatitis B and C virus infection in a Brazilian Eastern Amazon region. Arq Gastroenterol. 2010;47(1):35-41. doi: 10.1590/s000428032010000100007. [PubMed: 20520973].

23. Luksamijarulkul P, Maneesri P, Kittigul L. Hepatitis B sero-prevalence and risk factors among school-age children in a low socioeconomic community, Bangkok. Asia Pac J Public Health. 1995;8(3):158-61. doi: 10.1177/101053959500800302. [PubMed: 10050181].

24. Kahraman HG, Ozbek OA, Emek M, Atasoylu G, Sekreter O, Unal B. Hepatitis B seroprevalence and the relationship between being hepatitis b vaccinated and infected with social determinants of health: Manisa, 2014. Hepat Mon. 2018;18(7). e65395. doi: 10.5812/hepatmon.65395.

25. Bertolini DA, Pinho JR, Saraceni CP, Moreira RC, Granato CF, Carrilho FJ. Prevalence of serological markers of hepatitis B virus in pregnant women from Parana State, Brazil. Braz J Med Biol Res. 2006;39(8):108390. doi: 10.1590/s0100-879x2006000800011. [PubMed: 16906283].

26. Fathimoghaddam F, Hedayati-Moghaddam MR, Bidkhori HR, Ah- madi S, Sima HR. The prevalence of hepatitis B antigen-positivity in the general population of Mashhad, Iran. Hepat Mon. 2011;11(5):34650. [PubMed: 22087159]. [PubMed Central: PMC3212777].

27. Mutocheluh M, Owusu M, Kwofie TB, Akadigo T, Appau E, Narkwa PW. Risk factors associated with hepatitis B exposure and the reliability of five rapid kits commonly used for screening blood donors in Ghana. BMC Res Notes. 2014;7:873. doi: 10.1186/1756-0500-7-873. [PubMed: 25475050]. [PubMed Central: PMC4295511].

28. El Khouri M, Duarte LS, Ribeiro RB, da Silva LF, Camargo LM, dos Santos VA, et al. Seroprevalence of hepatitis B virus and hepatitis $\mathrm{C}$ virus in Monte Negro in the Brazilian western Amazon region. Clinics (Sao Paulo). 2005;60(1):29-36. doi: 10.1590/s1807-59322005000100007. [PubMed: 15838578]

29. Chen DS. Hepatitis B vaccination: The key towards elimination and eradication of hepatitis B. J Hepatol. 2009;50(4):805-16. doi: 10.1016/j.jhep.2009.01.002. [PubMed: 19231008].

30. Rajamoorthy Y, Radam A, Taib NM, Rahim KA, Munusamy S, Wagner AL, et al. Willingness to pay for hepatitis B vaccination in Selangor, Malaysia: A cross-sectional household survey. PLoS One. 2019;14(4). e0215125. doi: 10.1371/journal.pone.0215125. [PubMed: 30964934]. [PubMed Central: PMC6456223].

31. Zheng J, Li Q, Wang J, Zhang G, Wangen KR. Inequality in the hepatitis B awareness level in rural residents from 7 provinces in China. Hum Vaccin Immunother. 2017;13(5):1005-13. doi: 10.1080/21645515.2016.1265714. [PubMed: 28277091]. [PubMed Central: PMC5443380].

32. Guimaraes L, Brunini S, Guimaraes RA, Galdino-Junior H, Minamisava $\mathrm{R}$, da Cunha VE, et al. Epidemiology of hepatitis B virus infection in people living in poverty in the central-west region of Brazil. BMC Public Health. 2019;19(1):443. doi: 10.1186/s12889-019-6828-8. [PubMed: 31035990]. [PubMed Central: PMC6489193].

33. Kim YO. Access to hepatitis B vaccination among Korean American children in immigrant families. $J$ Health Care Poor Underserved. 2004;15(2):170-82. doi: 10.1353/hpu.2004.0027. [PubMed: 15253371].

34. Middleman AB, Robertson LM, Young C, Durant RH, Emans SJ. Predictors of time to completion of the hepatitis B vaccination series among adolescents. J Adolesc Health. 1999;25(5):323-7. doi: 10.1016/s1054139x(99)00063-4. [PubMed: 10551662].

35. Zhu D, Wang J, Wangen KR. Hepatitis B vaccination coverage rates among adults in rural China: are economic barriers relevant? Vaccine. 2014;32(49):6705-10. doi: 10.1016/j.vaccine.2013.06.095. [PubMed: 23845801]. 